\title{
Experimental Research of Stabilization of Polluted Marine Dredged Sediments By Using Silica Fume
}

\author{
Ernesto Silitonga ${ }^{1}$ \\ ${ }^{1}$ Universitas Negeri Medan, Civil Engineering Department, 20221 Medan, Indonesia
}

\begin{abstract}
In order to maintain the harbour activities, big amount of sediments are dredged every year. The traditional solution such as dumping the dredged sediments to the sea/river since its regulated in Europe, is not an option anymore. Therefore the beneficial reuse of polluted marine dredged sediments is urgently needed to realize. This study focused on reuse the dredged sediment in road construction. The main objective of this research is to enhance the physical, mechanical and chemical characteristics of the mix by incorporating binders sediments to fulfil the criteria in their use as material in road construction. The results show that the treatment by hydraulics binders and silica fume could satisfy the needed mechanical characteristics. The main reason of Silica Fume addition is its capability to trap the pollutants so that the pollutants could not escape from the matrix and pollute the environment. After the geotechnical study in laboratory results show as expected, then the study to identify the chemical characteristic realized. To evaluate the environmental impacts of the use material, leaching test are performed. The leaching test was performed to verify the predicted release of pollutants based on total dissolution. And for the final part, the test results show that the polluted marine dredged sediments could be safely used (in term of environmental impact) as a new material in road construction.
\end{abstract}

\section{Introduction}

Due to the increase of amount of marine dredged sediments, environmentally reuse of dredged sediment is urgently needed in France. Since the European regulation about the dredged sediment established [1], the port authority is encouraged to find solutions regardful the environmental issues. Available or attainable, there are many constraints on policy implementation need to be designed. However, before deciding if the dredged material is acceptable for a beneficial use, it is necessary to realize serial tests to evaluate the capability of marine dredged sediment in its reutilization domain.

Previous studies with different alternative treatment method to find the domain application for the reuse of marine dredged sediments have been investigated in Europe. This paper concentrate to determine the type and composition of binder to stabilize marine dredged sediments. The ideal percentage of hydraulic binders needed to meet prescribed specifications is very important. Silitonga in his research using dredged sediments from Cherbourg (France) [2], claimed that the ideal amount of hydraulic binder needed to stabilized dredged sediment was between 11\%-13\%. Behmanesh stabilized dredged sediment of Port du Havre. The amount of hydraulic binder utilized to stabilized dredged sediment was $15 \%$. [3]. Silitonga E., [4] needed $11 \%$ of pozzolanic binders (fly ash) to stabilized dredged sediment from Port de Cherbourg (France). Zhibo in his research, 
stabilized marine dredged sediment from Port of Cherbourg (France) with 15\% hydraulics binder. [5].

The primary goal of this research is to investigate the potential reuse of Marine dredged Sediment of Port-en-Bessin as material in road construction. Road construction needs to meet the requirements. In order to fulfil the requirements, the material has to have mechanical characteristics, furthermore if the material polluted. Consequently the addition of binders that capable to fulfil the mechanical requirements and environmental regulation is needed. In this study, the binder utilized to enhance the mechanical characteristics and to prevent the pollutants contaminate environment is Silica fume. Silica fume is by-product of producing certain metals in electric furnaces. Silica-fume, also known by other names such as volatilized silica, micro silica, or condensed silica fume, is a by-product of the induction arc furnaces in the silicon metal industries. From the previous studies [6] and [7], it is well known that the use of Silica Fume enhances the durability of concrete. The Silica Fume addition enhances the compressive strength and reduces the overall permeability of hardened concrete due to its pozzolanic properties, which result in finer hydrated phases (C-S-H gel) and densified microstructure. Raiess-Ghasemi [8] stated in his study that, concretes made with Silica Fume have a finer pore structure, with a lower proportion of fairly coarse capillary pores. For the same composition, these concretes are, therefore, generally denser than pure Portland cement concretes. One reason for this is a lower content of coarse $\mathrm{Ca}(\mathrm{OH}) 2$ crystals in the matrix and the aggregate surface zones of these concretes. Sobolev [9] confirmed in his research that a shift of the pore structure towards finer pores as a result of the pozzolanic reaction is also observed when Silica Fume is used in concrete. The results from several previous studies are the main reason why Silica Fume is being used in this study. Beside to fulfil the criteria needed in Road construction work, by enhancing the mechanical (physical) characteristic, the primary reason is the ability of Silica Fume as a filler and capable to trap the pollutant in to the densify microstructure, so that the pollutant will not break out and contaminate the environment.

\section{Materials and methods.}

\subsection{Materials}

This research is realized using marine sediments, were dredged from Port-en-Bessin, France. This harbour is considered as one of the oldest Harbour in France. Port-en-Bessin (PEB) is located in the Northwestern France. The sediments were dredged from four different locations; Avant port exterieur, Avant port interieur, Bassin no.1 and Bassin no. 2. After the dredging process, the marine sediments were taken and stored in experimental area, the experimental area was situated $1,3 \mathrm{~km}$ from the Harbour. The experimental area was specially designed and prepared for stabilisation of waste material work. The binder utilized in this study is Cement and Lime and Silica Fume. Cement and lime utilized are typical hydraulics binders used in soil stabilization work. Three different types of Silica Fume (FS) were utilized in this research (FS1, FS2 and FS3). The Silica Fumes utilized are not commercialized yet. In fact, the Silica Fumes used in this study are a prototype of lowcost Silica Fume. The particle size distribution of this Silica Fume is not as fine as Silica Fume that commercialized in the market.

\subsection{Index properties.}

\subsubsection{Particle distribution}


In order to identify the particle size of marine sediments, utilized, a laser diffractometer Coulter LS200 was used in this study.

Table 1. Particle size of marine sediment utilized

\begin{tabular}{|c|c|c|c|c|c|c|c|c|c|}
\hline & $\begin{array}{c}\text { PEB } \\
\text { A }\end{array}$ & $\begin{array}{c}\text { PEB } \\
\text { B }\end{array}$ & $\begin{array}{c}\text { PEB } \\
\text { C }\end{array}$ & $\begin{array}{c}\text { PEB } \\
\text { D }\end{array}$ & Lime & Cement & FS1 & FS2 & FS3 \\
\hline D10 $(\mu \mathrm{m})$ & 2 & 1.92 & 1.5 & 2.2 & 0.5 & 0.6 & 4 & 18.2 & 3.2 \\
\hline $\mathrm{D} 50(\mu \mathrm{m})$ & 12 & 11.1 & 10.6 & 12.5 & 11.3 & 32.6 & 32.3 & 153 & 26,4 \\
\hline $\mathrm{D} 90(\mu \mathrm{m})$ & 78.4 & 66.7 & 72 & 75.6 & 172 & 730 & 93 & 307 & 84 \\
\hline$<2 \mu \mathrm{m}(\%)$ & 10.7 & 10.6 & 13.8 & 9 & 18.3 & 15.2 & 7.3 & 2.3 & 13.8 \\
\hline $2-63 \mu \mathrm{m}(\%)$ & 77.2 & 78.8 & 74.8 & 78.8 & 63.1 & 53.3 & 70 & 18.9 & 68 \\
\hline$>63 \mu \mathrm{m}(\%)$ & 12.6 & 10.6 & 11.5 & 12.2 & 19.7 & 31.5 & 22.7 & 78.8 & 18.2 \\
\hline
\end{tabular}

The results as shown in Table 1, confirm that the particle distribution of marine dredged sediments that were taken from four different locations (PEAB-A, PEB-B, PEB-C and PEB-D) is almost similar, this means the homogeneity of the marine sediment of PEB. From the point of view of percentage most representative, it shown that marine sediments constituted a large amount particle with size between 2 - $63 \mu \mathrm{m}$. The Silica Fume type 3 has finer diameter of particle compared to Silica Fume type 2 (FS2) and Silica Fume type 1 (FS1).

\subsubsection{Mineralogical characterization.}

In this study, to examine the physico-chemical of dredged sediment of Port en Bessin, the researcher is using Powder X-ray Diffraction (XRD). It is known that with high percentage of smectite can cause problems during the treatment process.

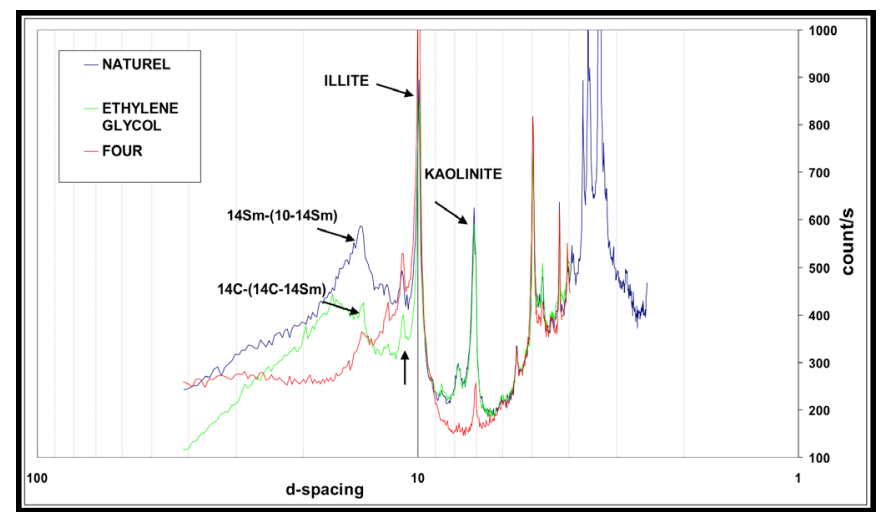

Fig 1. Diagram of mineralogical characteristics of marine sediments

As shown in Fig. 1, it appears that clay sediments of Port en Bessin phases are fairly composed of Smectite, Illlites, and Kaolinite, the presence of Illite and Kaolinite, will not risk importance consequence for the future treatment, however the present of Smectite will cause problem such as swelling. The result shows the percentage of Smectite is $32 \%$, this amount of Smectite considered as a warning of swelling problem in a future and as a reference of a choice of type of lime utilized.

\subsubsection{Chemical properties}

The marine sediment is considered as a waste material, therefore, it is necessary to assess the environmental risk of the dredged sediment before its land application Leaching Test 
was performed to identify the chemical properties of three different type of Silica Fume. The results of chemical characteristics are shown in Table 2. The amount of Micropollutants measured from Marine dredged sediment of Port en Bessin was presented in Table 2. In order to verify the level of pollution of the marine sediment, a reference established by European Council 2003/33/EC was used in this study. This reference divided in 3 classes: inert waste, non-hazardous and hazardous waste. These reference values relate to the elements contained in the leachate and not in the raw material

Table 2. Chemical characteristic of Marine Sediments

\begin{tabular}{|c|c|c|c|c|}
\hline \multirow{2}{*}{} & & \multicolumn{3}{|c|}{ European Council Reference } \\
\cline { 3 - 5 } Pollutants & $\begin{array}{c}\text { Port en } \\
\text { Bessin }\end{array}$ & $\begin{array}{c}\text { Inert } \\
\text { Waste }\end{array}$ & $\begin{array}{c}\text { Non } \\
\text { Hazardous } \\
\text { Waste }\end{array}$ & $\begin{array}{c}\text { Hazardous } \\
\text { Waste }\end{array}$ \\
\hline $\mathrm{As}(\mathrm{mg} / \mathrm{kg})$ & 4.9 & 0,5 & 2 & 25 \\
\hline $\mathrm{Cd}(\mathrm{mg} / \mathrm{kg})$ & 1.18 & 0,04 & 1 & 5 \\
\hline $\mathrm{Cr}(\mathrm{mg} / \mathrm{kg})$ & 70.4 & 2 & 50 & 100 \\
\hline $\mathrm{Cu}(\mathrm{mg} / \mathrm{kg})$ & 0.7 & 0,01 & 0,2 & 2 \\
\hline $\mathrm{Hg}(\mathrm{mg} / \mathrm{kg})$ & 0.58 & 0,01 & 0,2 & 2 \\
\hline $\mathrm{Pb}(\mathrm{mg} / \mathrm{kg})$ & 17.3 & 0,5 & 10 & 50 \\
\hline $\mathrm{Ni}(\mathrm{mg} / \mathrm{kg})$ & 19.8 & 0,4 & 10 & 40 \\
\hline $\mathrm{Zn}(\mathrm{mg} / \mathrm{kg})$ & 77.5 & 4 & 50 & 200 \\
\hline
\end{tabular}

Table 3. Chemical characteristic of Silica Fume utilized

\begin{tabular}{|c|c|c|c|}
\hline Parameters & Silica Fume 1 & Silica Fume 2 & Silica Fume 3 \\
\hline Colour & Light Gray & Blue & Dark Gray \\
\hline $\mathrm{SiO}_{2}$ & $90-92$ & $85-90$ & $90-95$ \\
\hline $\mathrm{Fe}_{2} \mathrm{O}_{3}$ & $1,5-2$ & $1,5-2$ & $1,5-2$ \\
\hline $\mathrm{AI} 2 \mathrm{O} 3$ & 1 & 1 & $1-1,5$ \\
\hline $\mathrm{CaO}$ & $0,5-1$ & $0,5-1$ & $0,5-1$ \\
\hline $\mathrm{MgO}$ & $1-1,5$ & $1-1,5$ & 1 \\
\hline $\mathrm{Na}_{2} \mathrm{O}$ & $0,5-1$ & $1-1,5$ & $0,8-1$ \\
\hline $\mathrm{K}_{2} \mathrm{O}$ & $1-1,3$ & $1-1,3$ & $1,3-1,5$ \\
\hline $\mathrm{C}$ & $0,5-1$ & $1-1,5$ & $1-1,5$ \\
\hline $\mathrm{free} \mathrm{Si}(\%)$ & $<0,2$ & $<0,4$ & $<0,4$ \\
\hline $\mathrm{Free} \mathrm{CaO}(\%)$ & $<1$ & $<2$ & $<1$ \\
\hline $\mathrm{SO}(\%)$ & $<1$ & $<2$ & $<1$ \\
\hline $\mathrm{Cl}(\%)$ & $<0,2$ & $<0,5$ & $<0,1$ \\
\hline
\end{tabular}

The reference values were shown in table 2. According to the European Council Reference, the marine sediments from Port en Bessin content a medium amount of pollutants, as shown in table 2, According to European reference, all amount of micropolluants from 4 different periods are categorized as non-hazardous waste. The differences in chemical analysis between FS1, FS2 and FS3 were shown in table 3. The previous study conducted by Silitonga [4], the result showed that the chemical properties can strongly effect the mechanical properties of the marine sediment stabilized. As shown in table 2, FS3 is characterized by a higher content of $\mathrm{SiO}_{2}$, followed by FS1 and FS2. Based on this result, we can expect that FS3 will be more reactive than FS2 as a binder. Silitonga [2] on his research noticed that, Silica Fume possesses higher content of $\mathrm{SiO}_{2}, \mathrm{Fe}_{2} \mathrm{O}_{3}$ or $\mathrm{Al}_{2} \mathrm{O} 3$ produces higher resistance on Unconfined Compressive Strength Test. On the other hand FS2 has higher total amount of free $\mathrm{CaO}$, Silitonga [4] on his previous research showed the amount of free $\mathrm{CaO}$ has a big role on providing strength on mechanical test such as Unconfined compressive Test and Tensile test 


\subsection{Methods}

\subsubsection{Preparations of Samples.}

After being dredged, physical characteristics of marine sediment were measured. The measured initial water content is about $169 \%$. The dewatering process was realized, the marine sediment, oven-dried for 5 days at $60^{\circ} \mathrm{C}$ was pulverized to $2 \mathrm{~mm}$ sieve size it was initially mixed with determined quantities of Silica Fume, lime and cement as a binder, in a dry state and subsequently mixed with water by a mechanical mixer with a speed of 150 $\mathrm{rd} / \mathrm{min}$ for a period of approximately 8 minutes (fig 2). After mixing the samples were prepared with the static compaction method, at the optimum moisture content and maximum density determined by Proctor test. Cylindrical specimens $(\varnothing=40 \mathrm{~mm}, \mathrm{~h}=$ $80 \mathrm{~mm}$ ) were used for unconfined compressive strength testing. The compressive strength is determined using a $10 \mathrm{kN}$ capacity automatic compression machine according to France regulation NF EN 196-1 (NF, 1995) on a simple speed cross-head moving machine at a speed of $1 \mathrm{~mm} / \mathrm{s}$. The samples were pushed out from the mold directly after completion of the compaction and were stored in the curing room until testing.

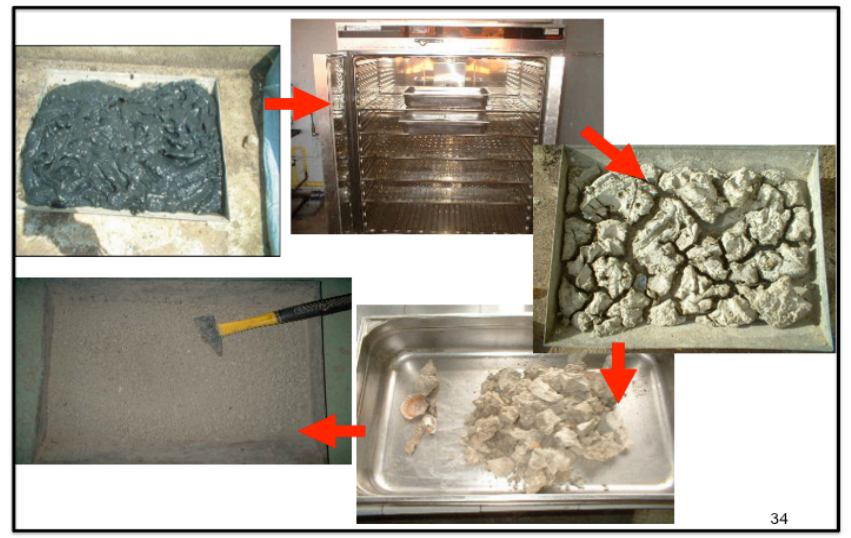

Fig. 2. Preparation of samples process

\subsubsection{Mix design.}

In order to identify the influence of the Silica Fume on the strength gained, samples FS1 FS2 and FS3 were set with different type of Silica Fume content. The different formulas in this experiment are given in Table 4. The goal of manufacturing SF2-A, was to compare the influence of using types different Silica Fume in the mixture. The amount of $2-5 \%$ of cement was the common amount that normally used in the road construction field, due to this reason. To identify the effect of sand to the mixture thus the amount of Sand utilized on this research varies from $5 \%-15 \%$.

\section{Results}

The goal of this study is to find an application for reuse of marine dredged sediments materials as a new material on road construction. Hence, serial tests need to be realized to identify if marine dredged sediment could be utilized for road construction. Serial tests of geotechnical characteristics that are specified in building rules such as Proctor Test, 
Unconfined Compressive Strength, Tensile Strength. These tests are aimed to determine either a specific material can or cannot be used as a material in road construction

Table 4. Composition of binders

\begin{tabular}{|c|c|c|c|c|c|c|}
\hline Name & FS1 & FS2 & FS3 & Lime & Cement & Sand \\
\hline $10-5-3-4 F S 1$ & 4 & - & - & 3 & 5 & $10 \%$ \\
\hline $10-5-3-4 F S 2$ & - & 4 & - & 3 & 5 & $10 \%$ \\
\hline $10-5-3-2$ FS3 & - & - & 4 & 3 & 5 & $10 \%$ \\
\hline $10-5-3-6 F S 1$ & 6 & - & - & 3 & 5 & $10 \%$ \\
\hline $10-5-3-6 F S 2$ & - & 6 & - & 3 & 5 & $10 \%$ \\
\hline $10-5-3-6 F S 3$ & & - & 6 & 3 & 5 & $10 \%$ \\
\hline $10-5-3-0 F S$ & - & - & - & 3 & 5 & $10 \%$ \\
\hline $10-3-3-4 F S 3$ & - & - & 4 & 3 & 3 & $10 \%$ \\
\hline $5-5-3-4 F S 3$ & - & - & 4 & 3 & 5 & $5 \%$ \\
\hline $0-5-3-4 F S 3$ & - & & 4 & 3 & 5 & $0 \%$ \\
\hline CEM1 & - & - & - & - & 7 & $10 \%$ \\
\hline
\end{tabular}

\subsection{Mechanical Characteristics.}

\subsubsection{Unconfined Compressive Strength (UCS).}

In order to identify the mechanical behavior of mixtures realized, the UCS test was performed. The results in fig 3 show that for curing age 7-14 days, sample mixed with 7\% of cement (CEM1) possesses highest UCS strength, this result because of the rapidity of cement hydration to provide strength. Cement hydration initiate as soon as water introduce to the mixture, normally hydration of cement reach its maximal at 14 days or 28 days of curing age. This theory confirmed why UCS value of CEM1 established the highest UCS values (from 7-14 age curing days) and doesn't show any remarkable amelioration UCS values after 14 days curing age. At 28 days the samples with Silica Fume (FS1, FS2 and FS3) show an increase UCS values greater than sample mixed only with $7 \%$ cement (CEM1). The hydration of Silica Fume is responsible for this increase. At 28 days, the reaction of normal pozzolans binders will not react perfectly on providing strength, this is because of pozzolans binders need help from cement/ lime hydration, in it self, do not have any cementious properties but when reacts with $\mathrm{Ca}(\mathrm{OH})_{2}$ on hydration of cement produces the gel i.e. calcium-silicate-hydrate $(\mathrm{C}-\mathrm{S}-\mathrm{H})$ which has good cementious properties. This reaction normally happened after 28 days of curing age for normal pozzolans binders (fly ash), because of high surface area and high content of amorphous silica in silica fume, this highly active pozzolan reacts more quickly than ordinary pozzolans. Effect of different type of Silica Fume (FS1, FS2 and FS3) can be noticed in Figure 3, the UCS values from 7 days to 180 days, the sample with $4 \%$ of Silica Fume type 3 (FS3) produces higher strength than samples with FS2 and FS1. This result confirm the theory that binder (especially pozzolanic binder) with finer particle size is more reactive, thus produce higher strength on mechanical properties. As shown before, Silica Fume type 3 (FS3) possesses finer particle size than FS1 and FS2, this is the main reason, why sample with FS3 gained higher strength. In the point of view of chemical properties, FS3 has almost similar content than FS1, we can assume that in this case, particle size distribution plays more important rule to provide strength than chemical properties of Silica Fume. that there isn't any important different between UCS values. At this case we consider that, the chemical properties of Silica Fume used in this study, are not high enough to make any different. According to regulation [4], after the addition of silica fume and hydraulic binders, the UCS values should reach at least $1 \mathrm{MPa}$ at 28 days of curing age. The test confirmed that all samples after stabilization process could be reused as a material in road construction. 


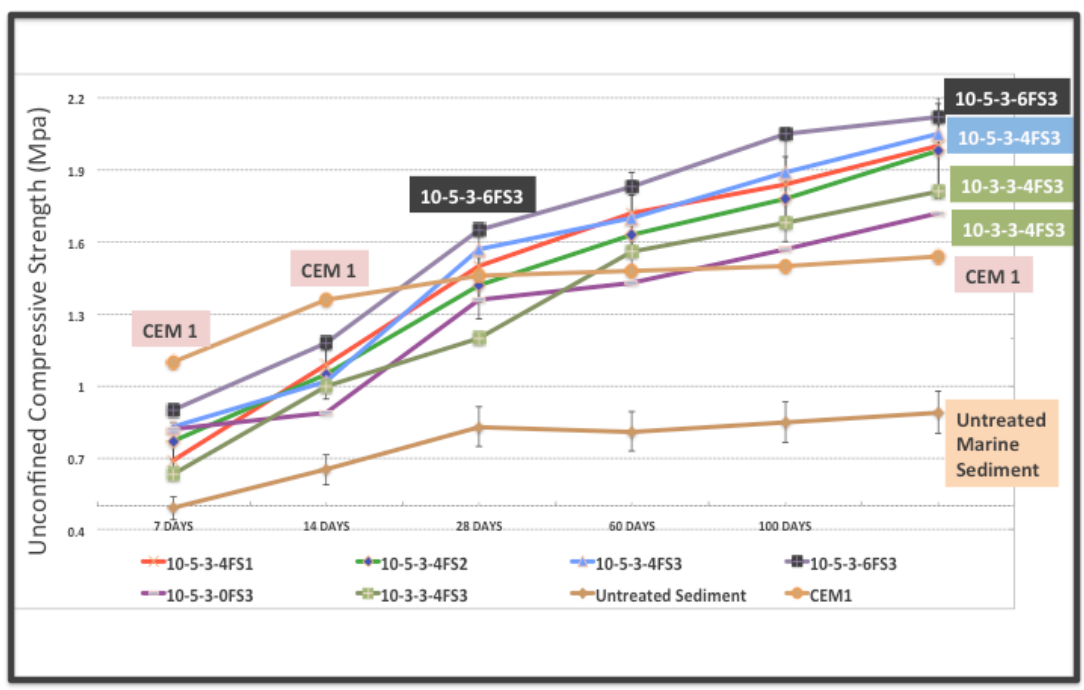

Fig 3. Unconfined Compressive Strength Test

\subsubsection{Tensile Strength (TS).}

The elastic modulus is obtained using a stress-strain curve of an unconfined compression test. Firstly, the maximum compression strength of the mixture is measured. Then the elastic modulus, E, is measured on another sample. In order to not damage the cylinders, the maximum effort applied corresponds to $30 \%$ of the maximum compression strength. The tests are conducted on 360 days aging cylinders. The results of tensile test are presented in fig 4.a, As shown in the figure, only the samples with $6 \%$ Silica fume located in class $\mathrm{S} 2$ ( $\mathrm{H}$ and $\mathrm{G})$. According to Scheme of road section and recommended engineering characteristics, the samples with $6 \%$ Silica fume in geotechnical view, as material are suitable and secure for sub base and Foundation. Test of California Bearing Ratio (CBR) need to be realized to confirm the selection of road layer. Previous study done by Silitonga [2], Colins [11] and Siham [12] confirmed that dredged marine sediment stabilized with fly ash or hydraulics binders (in geotechnical view) can be used in sub base and foundation layer in road construction base. In this study, the effect of Silica fume addition is remarkable in providing Elastic Modulus and Tensile strength. Despite Samples with 4\% Silica fume (A, B, C, D and E) in the same class with sample treated only with $7 \%$ cement (CEM 1), yet the Elastic Modulus values are immensely higher than CEM 1. The presents of Silica Fume with its filler effect, due to its fineness make the Silica Fume fit into space and fill the empty space between sediment grains and produces more solid bonds between sediment grain, this is the reason of the enhancement of Elastic Modulus because a stiffer material will have higher Elastic Modulus. The results show that the speciments with $4 \%$ of Silica fume (A, B, C, D) and sample treated only with cement (CEM 1) could be used as material only in sub base. In the other hand the samples with $6 \%$ of Silica fume ( $\mathrm{H}$ and $\mathrm{G})$ could be reused in sub base and foundation. The sample without Silica fume (F) is situated within the limit of S0 and S1 classes, it means the reuse for sub base need to be considered. 


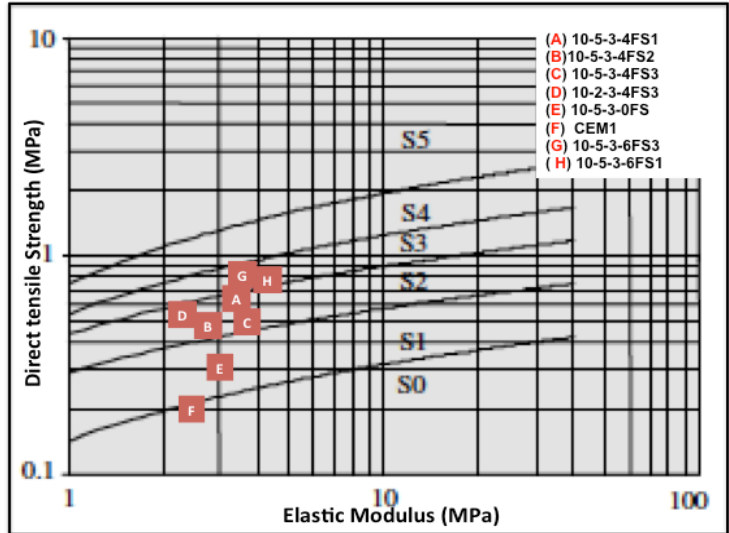

Fig 4.a. Tensile strength,

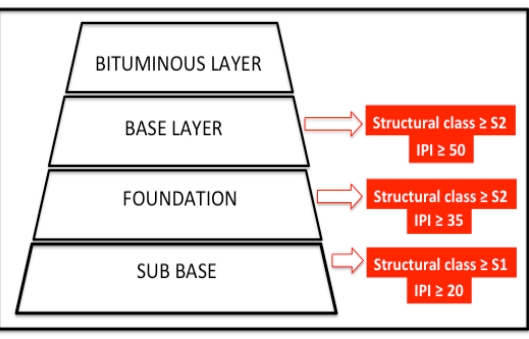

Fig 4.b. Scheme of road Section [4],

\subsubsection{Leaching Test}

The marine dredged sediment was planning to be reused as a base material in road construction. However, as the land applied dredged sediment is subjected to drying and oxidation, transformations in the chemical forms of heavy metals may affect their mobility and bioavailability may be occurred. The Leaching Test was realized according to French standard NF X 31-210 [13], refers to the solution containing the solubilized elements during the test, which are performed on the analytical characterization. This test is a simulation to identify the mixture reaction to aggressive chemical environment.

In order to classify the dredged sediment of ort en Bessin, the researcher decided to utilized reference values established by European Council No. 2003/33 / EC. The reference used to identify the amount of pollutants in sediment from the Port en Bessin. As shown in fig.5, the amount of Cadmium (cd) is $1.18 \mathrm{mg} / \mathrm{kg}$, according to European reference, the quantity of Cadmium categorized as non-hazardous waste. The leaching test for Cadmium (cd) show the stabilization of marine sediment, with or without Silica fume succeed to reduce the content of Cadmium in the mixture, (fig 5). Effect of Silica Fume in reducing the pollutants content is very dominant in this test. As shown in fig 5, all the samples without Silica fume; B, E, F, J, M, O and P (see fig 5), show unremarkable reduction amount of pollutant (for Cadmium), the samples are still in the same level of pollution as the original amount of pollutants of untreated marine sediment (non-hazardous waste level). Especially for sample utilized only cement (CEM1), show only 5\% reduction of pollutant from original amount of pollutants (untreated marine sediment). In the other hand, all the samples mixed with Silica fume, established a major reduction on amount of pollutant. The escalation of percentage of Silica fume (from $4 \%-6 \%$ ) produces more reduction of pollutant. The samples with $6 \%$ of Silica fume show a very remarkable reduction of pollutant. Sample with $6 \%$ of Silica fume established a group with lowest amount of pollutant (H, I, K, L, N and Q). One of the principle physical effect of silica fume is the filler, which because of its fineness can fit into space between sediment grains in the same way that sand fills the space between particles of coarse aggregates and cement grains fill the space between sand grains. 


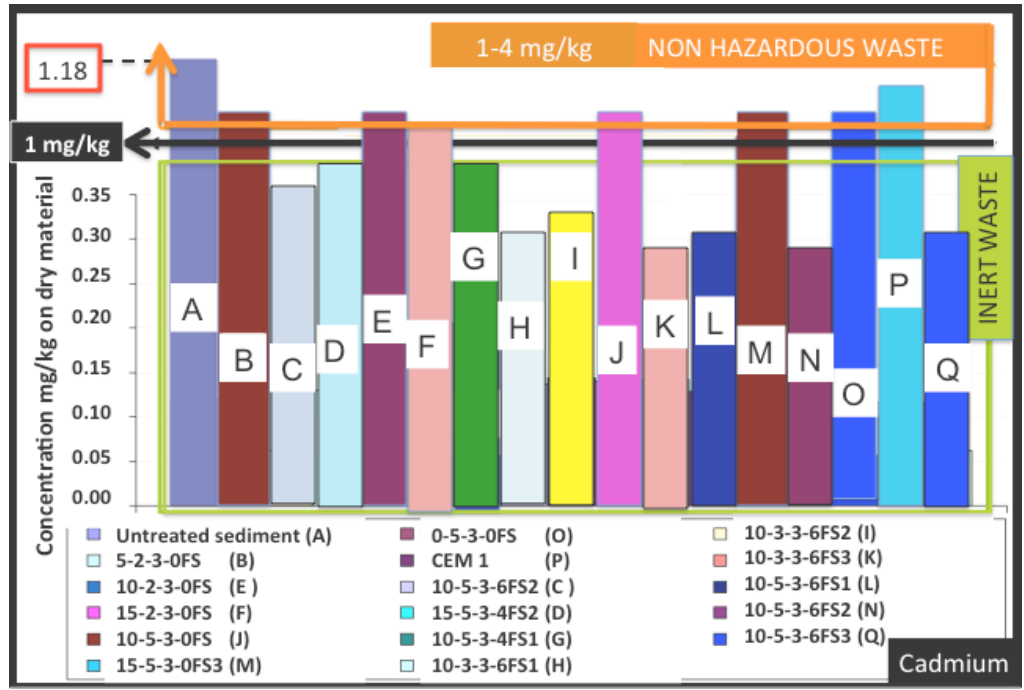

Fig 5. Leaching Test result for marine dredged sediment for Cadmium.

The theory is because of its finesess and after the pozzolans reaction, Silica Fume capable to trap the pollutants so that the pollutans could not escape from the matrix and pollute the environment. This is the main reason Silica Fume is being used in this study. After the results of leaching test presented in fig 5, the theory worked out excatlly as prediction. Except the effect of Silica fume, we can oberserve that the raise of percentage of cement, can enhance the reduction of pollutants. As figured, after addition of cement to $2 \%$ (to $5 \%$ from $3 \%$ Cement), the samples with $5 \%$ cement and $6 \%$ of Silica fume (C, N and Q) show a remarkble reduction of pollutants $(50 \%)$ compared to samples with $3 \%$ Cement $(\mathrm{H}, \mathrm{I}$ and $\mathrm{K})$. This results is due to hydration of cement which also produces $\mathrm{Ca}(\mathrm{OH}) 2$, required for the pozzolanic reaction in Silica Fume and for ion exchange in clays, which accelerates the cementitious and pozzolanic reaction of Silica fume. From the result of leaching test it confirmed that the present of Silica fume in the mixture (with addition of $4 \%-6 \%$ ) succeeded to reduce the pollutant concentration up to $50 \%$. According to European reference value for dredged sediment, In the environment point of view, after stabilization process with $4 \%$ to $6 \%$ of Silica fume, the marine dredged sediment categorized as inert waste, hence harmless to environment and could be reused as a material in road construction.

\section{Conclusion}

The general intention of this study is to find the domain application for the recycling of marine dredged sediment (contaminated). The reuse of marine dredged sediments as material in road construction purposes requires checking specific geotechnical and chemical criteria, it need to be considered, in order to identify the suitability of marine dredged sediment to be used in road construction. The distribution particle identification of marine dredged sediment from Port en Bessin show the homogeniety of Sediments and that it constituted a large amount particle with silty fraction $(2-63 \mu \mathrm{m})$. The result of leaching test confirmed that, Marine dredged sediment of Port en Bessin content amount of pollutants which is according to European Reference of Dredged sediment, categorized as non-hazardous waste. Several mixtures using marine dredged sediment, sand, cement, lime and Silica fume are realized. In order to identify the effect of Silica fume, cement and sand addition, mixtures are tested with different composition of binders. The experimental 
results for UCS show that all the samples successfully fulfill the criteria to be used in road construction. The effect of Silica addition identified to provide greater strength in UCS after 28 days of curing ages. Test on tensile strength confirmed that the sample with addition $6 \%$ Silica fume conformed to be used as material in sub base and foundation. In the other hand sample with $4 \%$ Silica fume only can be used in sub base. Leaching test determine that the present of silica in the specimens (either $4 \%$ or $6 \%$ ) remarkably capable to reduce the amount of pollutant (cadmium) and passed from level non-hazardous waste to categorize as inert waste. Hence the marine sediment with 4\%-6\% Silica fume can be used in road construction and harmless to the environment.

\section{References}

1. OSPAR Commission, Convention for the Protection of the Marine Environment of the North-East Atlantic, OSPAR Convention, 33p (1992)

2. E. Silitonga, Valorisation des sédiments marins contaminés par solidification/ stabilisation à base de liants hydrauliques et de fumée de silice. Thesis doctorat Université de Caen, France, 160p, (2010)

3. J. Behmanesh, Etude de la durabilité d'un sédiment, traité au ciment et additifs, Thèse de doctorat de l'Université de Caen. 214p (2008)

4. E. Silitonga, D. Levacher, S. Mezazigh, Effects of the use of fly ash as a binder on the mechanical behavior of treated sediments, Environmental Technology, vol 30, p 799807 (2009)

5. D. Zhibo, Charactérisation, stabilisation et solidification de sédiment marin. Thèse de doctorat, Université de Caen, 145p (2008)

6. J. J.Gaitero, I. Campillo, A. Guerrero, reduction of the calcium-leaching rate of cement paste by addition of silica nanoparticles. Cement Concrete Research, vol 38, p 1112 $1118(2008)$

7. Belkowitz JS, Armentrout D. An investigation of nano-silica in the cement hydration process. Proceeding 2010 concrete sustainability conference, national ready mixed concrete association, USA, p 1-15. (2010)

8. E. Silitonga, D. Levacher, S. Mezazigh, Utilization of fly ash for stabilization of marine dredged sediment, Revue Européenne de Génie Civil et Environnement, Vol 14 Issue 2, p 253-265, (2010)

9. P.J.P Gleize, A. Müller, et H.R. Roman, (2003). Microstructural investigation of a silica fume-lime mortar, Cement and Concrete Composites, Vol.25, pp.171-175.

10. European Standard, NF EN 14227-3, Hydraulically bound mixtures. Specifications. Fly ash bound mixtures, European Committee for Standarization (2013).

11. D. Colin, Valorisation de sediments fin de dragage en technique routière. Thesis doctorat, Université de Caen, France, 181p (2003)

12. K. Siham, B. Fabrice, A. Nor Edine, D. Patrick, Marine dredged sediment as new material source for road construction, Waste Manaegement no.28, p 919-218 (2008).

13. AFNOR NF X 31-210, Essai de lixiviation relatif a l'entreposage des dechet industriels stabilizes dans des sites de stockage Normalisation Francaise (1992). 